\title{
How Practice of Peer Assisted Learning Facilitates Better Learning among the Dental Students of Bangladesh
}

\author{
Dr. A.B.M. Rizwanur Rahman ${ }^{1}$, Professor Dr. Mohammad Faruque ${ }^{2}$, Dr. Kazi Khairul Alam ${ }^{3}$, Dr. Sanjida Tasnim ${ }^{4}$, \\ Dr. Mezbah Ul Azeez
}

\begin{abstract}
Peer assisted learning (PAL) is a common feature of medical education. PAL in the clinical setting, a complex learning environment, requires fresh evaluation. Socio-cultural theory is proposed as a means to understand educational interventions in ways that are practical and meaningful. This descriptive type of cross sectional study entitled practice of peer assisted learning among students in selected undergraduate dental colleges of Bangladesh was conducted in four Government and four non-Government dental colleges. The objective of this study was to explore the views of teachers and students regarding the benefits of practicing peer assisted learning. Sample size was 437 ( 407 students and 30 teachers). Data was collected from students with a self-administered semi-structured questionnaire and from dental teachers with indepth interview schedule. Data was analyzed by using SPSS 19. Most of the students opined that PAL method increased their knowledge. In the study most of the teacher said that PAL increased the confidence of the students and enhanced the conception about the topics. Teachers also said PAL developed good behavior of the students and also developed helping approach to others. This study finding showed that PAL method was very effective in higher education courses. So we should encourage the students and the teachers about the method.
\end{abstract}

Key Words: Peer-assisted learning (PAL), Knowledge, Reciprocity, Benefits

\section{Introduction}

Peer-assisted learning (PAL) as an educational method has been around since Socrates and Plato began questioning one another's ideas in small groups. In recent times, PAL has gained increasing attention across many different healthcare disciplines and educational sectors. Peer assisted learning (PAL) has been defined as People from similar social groupings, who are not professional teachers, helping each other to learn and learning themselves by teaching although (PAL) is widely used within undergraduate medical and dental education ${ }^{1}$. Reciprocity is the key to adopting the role of teacher and simply transmitting knowledge, the peer assisted learning process enables the peer assisted learning leader to enhance their own learning experience. Educational institutes aim to provide a program for preparing students with appropriate knowledge, skills and

1. Head \& Assistant Professor, Periodontology \& Oral Pathology Department, Dhaka Community Medical College Dental Unit

2. Head, Department of Dental Anatomy, Dhaka Dental College

3. Assistant Professor, Educational Science, Centre for Medical Education (CME), Mohakhali, Dahaka.

4. Lecturer, Department of Science of Dental Materials Marks Medical College Dental Unit

5. Assistant Professor \& Head, Department of Oral Anatomy \& Physiology, Dhaka Community Medical College Dental Unit

Address of correspondence: Dr. A.B.M. Rizwanur Rahman Head \& Assistant Professor, Periodontology \& Oral Pathology Department, Dhaka Community Medical College Dental Unit Email: sharafat.malek@gmail.com attitudes. The training program should enable trainees to act with a high level competency and performance when they encounter the real situations in workplaces ${ }^{2}$. Therefore it is important that the educational program applies appropriate teaching strategies to reach this goal.

The benefits of (PAL) are well established with positive effects on examination scores, student satisfaction and personal and professional development reported. PAL has been defined as "the development of knowledge and skill through active help and support among equal companions". It is this reciprocity of learning among other things that makes PAL such an attractive idea to educationalists. This is particularly true in medical education, where the restrictions on resources have forced teachers to look to creating new educational environments which can be delivered at a lower cost. The benefits associated with PAL, however, are not confined to examination scores.

PAL can assist the institution to meet external expectations for medical graduates to achieve competency and experience in both teaching and assessment, and may help to instill a life-long culture of teaching. PAL can also address specific gaps within the curriculum, providing additional student support in preparation for assessments ${ }^{3}$.

In Bangladesh dental education system the teacher student ratio is not satisfactory. It is very difficult to understand the content completely for all the students within limited duration of class. On the other hand one class does not contain same caliber of students. Those students who can't understand the contents fully may consult with their friends or seniors to clarify the contents. It is really helpful for them.

Bangladesh Journal of Medical Education 2018;9(2):16-18.. C 2018 Rahman et al., publisher and licensee Association for Medical Education. This is an Open Access article which permits unrestricted non-commercial use, provided the original work is properly cited. 
As a consequence students are not engaged in coaching so that they can save money and time. Similarly, the students who teach others can achieve confidence on that content. The aim of this study was to explore the merits and demerits as well as its impact on students' peer assisted learning.

\section{Methods}

This descriptive type of cross sectional study entitled practice of PAL among the students of selected undergraduate dental colleges of Bangladesh, was conducted in four Government and four non-Government dental colleges. Total 30 teachers and 407 students were included in this study. All teachers included head of the department, senior lecturer, lecturer of the every department and all the students in selected undergraduate dental colleges were the study population. Data were collected from dental teachers with in-depth interviews and from dental students with a self-administered semi-structured questionnaire. All the data were checked, edited to reduce errors and arranged manually in SPSS 19 version for analysis. The collected data were duly entered, processed and analyzed. Some of the data were presented in the form of tables and graphs.

\section{Results}

Table 1: Distribution of students regarding the benefits of sharing learning with classmate

\begin{tabular}{|c|c|c|c|c|c|c|c|}
\hline $\begin{array}{l}\text { The benefits of sharing } \\
\text { learning }\end{array}$ & $\begin{array}{c}\text { Strongly Agree } \\
f(\%)\end{array}$ & Agree $f(\%)$ & $\begin{array}{l}\text { Neither Agree nor } \\
\text { Disagree } f(\%)\end{array}$ & $\begin{array}{c}\text { Disagree } \\
f(\%)\end{array}$ & \begin{tabular}{|c|} 
Strongly \\
disagree $f(\%)$
\end{tabular} & Mean \pm SD & $\mathrm{CV}$ \\
\hline $\begin{array}{l}\text { It increases students } \\
\text { understanding }(\mathrm{n}=406)\end{array}$ & $266(65.5)$ & $115(28.3)$ & $6(1.5)$ & $15(3.7)$ & $4(1.0)$ & $\begin{array}{c}4.54 \\
0.787\end{array}$ & $17.3 \%$ \\
\hline $\begin{array}{l}\text { It has opportunity to clarify } \\
\text { complex concepts }(n=404)\end{array}$ & $224(55.4)$ & $155(38.4)$ & $12(3.0)$ & $11(2.7)$ & $2(0.5)$ & $\begin{array}{c}4.46 \\
0.729\end{array}$ & $16.3 \%$ \\
\hline $\begin{array}{l}\text { It increases students' } \\
\text { confidence }(\mathrm{n}=407)\end{array}$ & $225(55.3)$ & $115(38.1)$ & $18(4.4)$ & $9(2.2)$ & $0(0.0)$ & $\begin{array}{c}4.46 \\
0.686\end{array}$ & $15.3 \%$ \\
\hline $\begin{array}{l}\text { It increases passing rate of } \\
\text { students }(n=406)\end{array}$ & $184(45.3)$ & $171(42.1)$ & $38(9.4)$ & $11(2.7)$ & $2(0.5)$ & $\begin{array}{c}4.29 \\
0.785\end{array}$ & $18.3 \%$ \\
\hline $\begin{array}{l}\text { It minimizes overloading of } \\
\text { memorizing }(\mathrm{n}=405)\end{array}$ & $170(42.0)$ & $168(41.5)$ & $44(10.9)$ & $18(4.4)$ & $5(1.2)$ & $\begin{array}{c}4.19 \\
0.886\end{array}$ & $21.1 \%$ \\
\hline $\begin{array}{l}\text { It increases teaching skills of } \\
\text { students }(n=404)\end{array}$ & $155(38.4)$ & $191(47.3)$ & $30(7.4)$ & $19(4.7)$ & $9(2.2)$ & $\begin{array}{c}4.15 \\
0.909\end{array}$ & $21.9 \%$ \\
\hline $\begin{array}{l}\text { It decreases the loads of } \\
\text { teachers }(n=405)\end{array}$ & $83(20.5)$ & $175(43.2)$ & $91(22.5)$ & $48(11.9)$ & $8(2.0)$ & $\begin{array}{c}3.68 \\
0.992\end{array}$ & $26.9 \%$ \\
\hline $\begin{array}{l}\text { It reduces the cost of } \\
\text { education }(n=404)\end{array}$ & $83(20.5)$ & $134(32.9)$ & $89(22.0)$ & $57(14.1)$ & $41(10.1)$ & $\begin{array}{c}3.40 \\
1.243\end{array}$ & $36.5 \%$ \\
\hline
\end{tabular}

Table 1 shows the benefits of sharing learning with classmates. The benefits of sharing were calculated considering strongly disagree as 1 , disagree as 2 , neither agree nor disagree as 3, agree as 4 and strongly disagree as 5 . In this table we can recognize that all benefits of peer assisted learning were most effective since the mean values of the collected data were above 4 . However in case of 'decreases the loads of teachers' and 'reduce the cost of education' were not so effective because their means were less than 4 . All the aspects of benefits have moderate coefficient of variance ranged from $15 \%$ to $37 \%$.

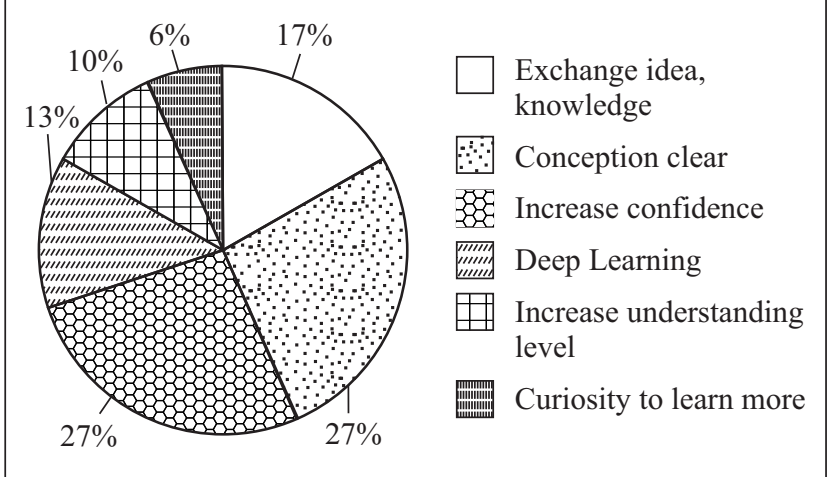

Figure 1: Distribution of teachers by their opinion regarding benefits of practice of peer assisted learning

Figure 1 displays distribution of teachers by their opinion regarding benefits of practice of peer assisted learning. Most of the teachers believed that by practicing PAL increased confidence and clear the conception about contents of the students. By teachers belief the rate of curiosity to learn more was less assimilated by practicing peer assisted learning. 


\section{Discussion}

Dental practice is based around contextualizing knowledge and applying it to patients in a clinical situation. In this study we revealed that PAL provides an additional opportunity for the students to achieve this. In addition, with the diverse range of individuals in a community, practitioners know that techniques constantly have to be modified and adapted to the needs of the individuals in a community; practitioners know that techniques constantly have to be modified and adapted to the needs of the individual patient or client. It appeared that the PAL helped students with this understanding by providing case scenarios. PAL gave students time to practice communication skills through role-playing and also helpful for improving the knowledge and skills. It helps the students to improve their confidence.

All the benefits (mentioned in this study) of PAL were most effective as their means were above 4 except in case of 'decreases the loads of teachers' and reduces the cost of education' because their means were less than 4 (3.68 and 3.4). All the aspects of benefits have moderate coefficient of variance ranged from $15 \%$ to $37 \%$. In Henning's s study we found that students experienced mutual benefits whether they are on the giving or receiving end of PAL interactions. Menezes $\mathrm{A}^{5}$ suggested in his study that by practicing peer assisted learning participants were inspired to engage themselves in teaching activities (as a tutor/teacher) during their medical career.

Regarding benefits of practice of PAL by the opinion of teachers most of them assumed that by practicing PAL the confidence and conception about contents of the students was amplified. The frequency of curiosity to learn more was less acquired by practicing peer assisted learning.

\section{Conclusion}

Higher education is not an easy process for students, requiring them to learn new material, develop higher order cognitive skills and to become successful. Whereas academic staff are responsible for presenting content and also contribute to the development of certain cognitive skills, this study demonstrates, how successful the PAL students can be better equipped than lecturers to help those in their PAL guidance to become expert students. The study findings indicate that the PAL scheme helps students though their study with perceived benefits to both PAL attendees and mentors.

\section{References}

1. Topping KJ, Jan G. M. Kooloos, Tim Klaassen, Sascha van Kuppeveld, Sanneke Bolhuis, Marc Vorstenbosch: The effectiveness of peer tutoring in further and higher education: A typology and review of the literature. Higher Education (Historical Archive), Scientific Research, 1996, 32:321-345.

2. Wadoodi, A. and J.R. Crosby, Twelve tips for peerassisted learning: a classic concept revisited. Med Teach 2002. 24(3): p. 241-4

3. Burgess A, McGregor D, Mellis C. Medical students as peer tutors: a systematic review.BMC Medical Education 9 June 2014, 14:115;

4. Henning, Weidner, Marty. Peer assisted learning in clinical education. Athletic Training Education Journal; 2008; 3(Jul-Sep):84-90.

5. Audrey M, Burgess A, Clarke AJ, Mellis C. Peerassisted learning in medical school: tutees' perspective. Advances in Medical Education and Practice, 18 January 2016. 39-43.

Bangladesh Journal of Medical Education 2018;9(2):16-18. 